Erratum

MICHAEL HEFFERNAN and HEIKE JÖNS

\title{
DEGREES OF INFLUENCE: THE POLITICS OF HONORARY DEGREES IN THE UNIVERSITIES OF OXFORD AND CAMBRIDGE, 1900-2000
}

\author{
ERRATUM TO: MINERVA (2007) 45(4) \\ DOI $10.1007 / \mathrm{s} 11024-007-9065-8$
}

In the article by Michael Heffernan and Heike Jöns, 'Degrees of Influence: The Politics of Honorary Degrees in the Universities of Oxford and Cambridge, 1900-2000', Minerva 45 (4), (2007), DOI 10.1007/s11024-007-9065-8, the final sentence of the Abstract (p. 389) should read: 'This essay describes the role of honorary degrees in the production and reproduction of the cultural and intellectual authority of these two ancient universities.' The reference in the second line of Footnote 22 (p. 395) should read: 'Werner Schochów, Die Preußische Staatsbibliothek, 1918-1945 (Cologne: Böhlau, 1988), 27.' The reference in Footnote 91 (p. 415) to 'note 3' should read: 'note 2 '.

MICHAEL HEFFERNAN

School of Geography

University of Nottingham

University Park

Nottingham NG7 2RD

$U K$

E-mail: Mike.Heffernan@nottingham.ac.uk

HEIKE JÖNS

Department of Geography

Loughborough University

Loughborough LE11 3TU

UK

E-mail:H.Jons@lboro.ac.uk

The online version of the original article can be found under doi: 10.1007/s11024-007-9065-8. 